\title{
Bulked Segregant Analysis Identifies Molecular Markers Linked to Melampsora medusae Resistance in Populus deltoides
}

\author{
G. M. Tabor, T. L. Kubisiak, N. B. Klopfenstein, R. B. Hall, and H. S. McNabb Jr.
}

First and fifth authors: Departments of Forestry and Plant Pathology, Iowa State University, Ames 50011; second author: USDA Forest Service, Southern Research Station, Southern Institute of Forest Genetics, 23332 Highway 67, Saucier, MS 39574; third author: USDA Forest Service, Rocky Mountain Research Station, Forestry Sciences Laboratory, 1221 South Main, Moscow, ID 83843; and fourth author: Department of Forestry, Iowa State University, Ames 50011. Accepted for publication 26 May 2000.

\section{ABSTRACT}

Tabor, G. M., Kubisiak, T. L., Klopfenstein, N. B., Hall, R. B., and McNabb, H. S., Jr. 2000. Bulked segregant analysis identifies molecular markers linked to Melampsora medusae resistance in Populus deltoides. Phytopathology 90:1039-1042.

In the north central United States, leaf rust caused by Melampsora medusae is a major disease problem on Populus deltoides. In this study we identified molecular markers linked to a $M$. medusae resistance locus ( $L r d 1$ ) that was segregating 1:1 within an intraspecific $P$. deltoides family (C9425DD). Previous field results were confirmed in the controlled environment of a growth chamber through an excised whole-leaf inoculation method. Using bulked segregant analysis we identified two random amplified polymorphic DNA (RAPD) markers $\left(\mathrm{OPG} 10_{340}\right.$ and OPZ19 ${ }_{1800}$ ) that are linked to $L r d 1$. Based on segregation in a total of 116 progeny, the genetic distances between OPG10 340 and OPZ19 1800 and the resistance locus were estimated as 2.6 and 7.4 Haldane centimorgans $(\mathrm{cM})$, respectively. Multipoint linkage analyses strongly suggest the most likely order for these loci is $\operatorname{Lrd1}$, OPG10 ${ }_{340}$, and OPZ19 1800 . These markers may prove to be instrumental in the eventual cloning of $L r d 1$, as well as for marker-assisted selection of leaf-rust resistant genotypes.

Additional keywords: intraspecific hybrids, polymerase chain reaction, resistance genes.
Leaf rust caused by Melampsora spp. is a major disease of eastern cottonwood (Populus deltoides Bartram ex Marshall) and other poplars around the world. In the north central United States, Melampsora medusae Thum is the primary cause of leaf rust on eastern cottonwood $(1,25)$. Leaf rust can cause severe defoliation, thereby reducing growth during the growing season and increasing the risk of winter injury when damaged leaves fail to respond to decreasing day length and do not induce hardiness in the stems. The effect of leaf rust on yield varies among poplar clones and environment, but up to $60 \%$ reduction in wood production has been reported (22). Occasionally, leaf rust causes death of both young and mature trees.

Interest in poplar culture is increasing mainly because of their fast growth and ease of propagation. Consequently, efforts are intensifying to breed and select poplars for a variety of traits, including leaf rust resistance. Selection for leaf rust resistance can be facilitated by molecular genetic markers. Tight linkages between molecular genetic markers and rust resistance loci can serve as a basis for efforts to clone these genes and subsequent efforts to determine mode of action at the biochemical level.

For most tree crops including poplars, classical genetic analysis is not sufficiently developed to take full advantage of available marker technologies. However, techniques such as bulked segregant analysis (BSA; 14) enable tree breeders to identify genetic markers based on minimal classical genetic information (5). This

Corresponding author: G. M. Tabor; E-mail address: gtabor@iastate.edu

Use of trade names does not constitute endorsement by the USDA Forest Service.

Publication no. P-2000-0713-01R

This article is in the public domain and not copyrightable. It may be freely reprinted with customary crediting of the source. The American Phytopathological Society, 2000 is especially important because inbred lines are rarely used in tree breeding. Instead, highly heterozygous parents are crossed and, in Populus improvement, the best individual progeny are cloned for commercial use.

Recently, we characterized leaf rust resistance in a $P$. deltoides family that is controlled by a single locus, $\operatorname{Lrd} 1$ (20). Progenies of a cross between the two $P$. deltoides clones (family C9425DD) segregated 1:1 (immune/susceptible) for resistance to a number of $M$. medusae isolates, indicating that a single locus is involved. The phenotypes exhibited distinct resistance classes. Resistant clones were immune, whereas susceptible clones were heavily rusted. This family of $P$. deltoides was used to detect molecular markers linked to the M. medusae resistance locus, Lrd1. Because this family is an intraspecific cross of $P$. deltoides, it provides ideal material for identifying a rust-resistance gene that is derived from the coevolution of $P$. deltoides and $M$. medusae. In this paper, we report on two molecular genetic markers linked to the leaf rust-resistance locus $L r d 1$ in the intraspecific $P$. deltoides family C9425DD.

\section{MATERIALS AND METHODS}

Plant material. A progeny test was planted at Ames, Iowa as part of an overall Populus improvement program (13). One of the crosses tested was between two $P$. deltoides clones obtained from the University of Illinois (7), 7300501 (female and rust susceptible) and 7302801 (male and rust resistant). At the end of the first growing season, 227 progeny in this family were evaluated for field resistance to $M$. medusae.

For BSA, it was necessary to confirm the phenotypes of the parents and progeny through the excised whole-leaf inoculation method. Hardwood cuttings were made from both parents and 116 progeny to produce suitable leaves for the leaf assay. Of the 
116 progeny, 73 were leaf rust resistant under field conditions and 43 were leaf rust susceptible. The overall reduction in clone numbers after three growing seasons was due to severe deer browsing that limited the growth of many clones and a strong tendency for susceptible plants to suffer winter injury and be stunted or killed. All cuttings were planted in plastic containers and maintained in a greenhouse until they produced vigorous shoot and root systems. These plants were occasionally cut back to induce robust and uniform shoot growth.

Maintenance of M. medusae isolates. Urediospores of M. medusae were collected from the rust-susceptible progeny located at Iden Farm (Ames, IA). A monouredium isolate (IA-48) was increased on detached leaves of the universal suscept Populus $\times$ euramericana (Dode) Guinner cv. I-488 (18). Detached leaves of cv. I-488 were placed abaxial side up in a petri plate containing moist filter paper soaked with $10 \mathrm{mg} /$ liter gibberellin $\mathrm{A}_{3}$ potassium salt (Sigma Chemical Co., St. Louis). After IA-48 was increased on detached leaves, whole cv. I-488 plants were used to produce a large quantity of inoculum. Whole plants were inoculated with urediospores produced on detached leaves and kept in a dark dew chamber for $12 \mathrm{~h}$ at $20^{\circ} \mathrm{C}$. Subsequently, inoculated plants were maintained in a growth chamber on a 16-h photoperiod photoperiod with day and night temperatures of 20 and $18^{\circ} \mathrm{C}$, respectively. After 7 days of incubation, urediospores were collected on aluminum foil by lightly tapping uredia-containing leaves. Collected urediospores were used immediately to inoculate excised leaves of the parents and progeny.

Inoculation. For the excised leaf assay, leaves of the same position on the stem (Leaf Plastochron Index (LPI) 7 to 10; [10]) were harvested from the parents, progeny, and the universal suscept. After a brief rinse with distilled water, each leaf was placed abaxial side up in a petri plate containing moist filter paper soaked with $10 \mathrm{mg} /$ liter gibberellin $\mathrm{A}_{3}$ potassium salt. Fresh urediospores were suspended in distilled water containing a small amount of Tween 20 to disperse the hydrophobic spores to a final concentration of $\approx 20$ urediospores per microliter. Ten 20 - $\mu$ l droplets (five droplets on each side of the leaf midrib) were applied on the abaxial side of each leaf. After inoculation, plates were wrapped with parafilm and incubated for 7 days in a growth chamber with a 16-h photoperiod of photosynthetically active radiation of 126 to $141 \mu \mathrm{m} \mathrm{s}^{-1} \mathrm{~m}^{-2}$ and day and night temperatures of 20 and $18^{\circ} \mathrm{C}$, respectively. Inoculations were replicated three times. Data were scored as resistant ( 0 uredia per leaf) or susceptible ( $\geq 1$ uredia per leaf).

DNA sample preparation. A modified Doyle and Doyle (4) method was used to extract DNA from leaf tissue. Approximately $2 \mathrm{~g}$ of young leaf material was harvested from each parent and progeny and ground to fine powder in a sterile mortar prechilled by liquid nitrogen. Ground leaf material was placed immediately in $1.5 \mathrm{ml}$ of preheated $\left(60^{\circ} \mathrm{C}\right) 3 \%$ hexadecyltrimethyl ammoniumbromide buffer containing $1.4 \mathrm{M} \mathrm{NaCl}, 0.2 \%$ 2-mercaptoethanol, $20 \mathrm{mM}$ EDTA, and $100 \mathrm{mM}$ Tris-HCl (pH 8.0) and incubated for $1 \mathrm{~h}$ at $60^{\circ} \mathrm{C}$. The slurry was mixed periodically to ensure uniform distribution of the buffer. After incubation, the slurry was cooled to room temperature before adding an equal volume of chloroform/isoamyl alcohol (24:1). After gentle mixing, the preparations were centrifuged at $1,600 \times g$ for $10 \mathrm{~min}$. The aqueous phase was transferred into a sterile tube and reextracted with an equal volume of chloroform. Subsequently, the aqueous phase was transferred to a sterile tube, and $2 / 3$ volume of cold isopropanol was added to precipitate nucleic acids. Flocculent nucleic acids were transferred to a microcentrifuge tube with a transfer pipet and briefly centrifuged at low rpm to remove the remaining solvent. The soft pellet was washed with wash buffer (76\% ethanol and $10 \mathrm{mM}$ sodium acetate). The final pellet was resuspended in Tris-EDTA (TE) buffer (10 mM Tris and $1 \mathrm{mM}$ EDTA at $\mathrm{pH} 8.0)$ and digested with RNase A $(10 \mu \mathrm{g} / \mathrm{ml})$ until the RNA was undetectable by $1 \%$ agarose gel electrophoresis. After RNase digestion, the DNA preparations were extracted twice with equal volumes of chloro- form. Following transfer of the aqueous phase to a new microcentrifuge tube, $2.5 \mathrm{vol}$ of cold ethanol (100\%) containing $10 \mathrm{mM}$ sodium acetate was added to precipitate the DNA using highspeed centrifugation. The resulting pellets were washed with $70 \%$ ethanol, dried in a speed vacuum, and resuspended in TE buffer for quantification and purity analysis. A portion of the concentrated stocks was used to make $25 \mathrm{ng} / \mu \mathrm{l}$ polymerase chain reaction (PCR) stocks. Two DNA bulks, one for leaf rust immune and one for susceptible, were made by mixing equal volumes of DNA solution from each of 10 respective progeny. DNA from the two parents and the two bulks was used for random amplified polymorphic DNA (RAPD)-PCR.

PCR and electrophoresis. For RAPD amplification, oligonucleotide (10-mer) primers were obtained from Operon Technologies Inc. (Alameda, CA) and J. Hobbs (University of British Columbia, Vancouver). DNA amplification was based on previously published protocols (23). Reaction mixtures consisted of the following in $24 \mu \mathrm{l}$ total volume: $6.25 \mathrm{ng}$ of template DNA, $1 \mu \mathrm{l}$ of primer DNA ( $5 \mathrm{M}$ stock), $3.6 \mu \mathrm{l}$ of dNTPs (1 mM stock), $2.4 \mu \mathrm{l}$ of $10 \times$ Taq DNA polymerase reaction buffer $(500 \mathrm{mM} \mathrm{KCl}, 100 \mathrm{mM}$ Tris- $\mathrm{HCl}, 1.0 \%$ Triton $\mathrm{X}-100$, and $15 \mathrm{mM} \mathrm{MgCl}_{2}$ ), and 0.8 units of $\mathrm{Taq}$ DNA polymerase. Reactions were loaded in flexible microtiter plates and overlaid with $25 \mu \mathrm{l}$ of mineral oil. Microtiter plates were placed in preheated $\left(85^{\circ} \mathrm{C}\right)$, programmable temperature cyclers (MJ Research Inc., Watertown, MA) and covered with mylar film. DNA samples were amplified with the following thermal profile: $5 \mathrm{~s}$ at $95^{\circ} \mathrm{C} ; 1 \mathrm{~min}$ and $55 \mathrm{~s}$ at $92^{\circ} \mathrm{C}$; followed by 45 cycles of $5 \mathrm{~s}$ at $95^{\circ} \mathrm{C}, 55 \mathrm{~s}$ at $92^{\circ} \mathrm{C}, 1 \mathrm{~min}$ at $35^{\circ} \mathrm{C}$, and $9 \mathrm{~min}$ at $72^{\circ} \mathrm{C}$. Completed reactions were electrophoresed in $2 \%$ agarose gels and Tris-acetate-EDTA (TAE) buffer (40 mM Tris base, $20 \mathrm{mM}$ sodium acetate, and $2.0 \mathrm{mM}$ EDTA for glacial acetic acid to $\mathrm{pH} 7.2)$ for $3.5 \mathrm{~h}$ at $3 \mathrm{~V} / \mathrm{cm}(150 \mathrm{~V})$. To each reaction, $3.0 \mu \mathrm{l}$ of loading buffer (10× TAE, $50 \%$ glycerol, and $0.25 \%$ bromophenol blue) was added prior to electrophoresis. After electrophoresis, the gels were stained with ethidium bromide $(0.4 \mu \mathrm{g} / \mathrm{ml})$ for $45 \mathrm{~min}$, washed in distilled $\mathrm{H}_{2} \mathrm{O}$ for $1.0 \mathrm{~h}$, and photographed by UV light.

\section{RESULTS}

For field observations made on the 227 full-sib progeny at the end of their first growing season, 117 progeny were susceptible and 110 were field resistant. A chi-square test for fit to a 1:1 segregation ratio failed to reject this hypothesis $\left(\chi^{2}=0.22\right.$ with $\left.1 \mathrm{df}, P=0.64\right)$. The most logical explanation for these results was that the resistant parent was heterozygous for a dominant resistance allele.

Results from the excised leaf inoculations were consistent with the field experiment. Clones that were immune or susceptible in the field were again classified as immune or susceptible to the monouredium isolate (IA-48) in the excised whole-leaf experiments. These results allowed us to construct two DNA bulks from progeny that were phenotypically distinct as rust immune or rust susceptible.

Initial screening of the parents and bulks with 1,200 primers identified 84 10-mer primers that amplified putatively polymorphic bands between the samples. However, when these 84 primers were used to further characterize the individual progeny comprising the bulks, only two primers amplified bands that were consistently polymorphic between the resistant and susceptible progeny arrays.

One of these two primers, OPG-10 (Operon Technologies), produced a polymorphic band $\left(\mathrm{OPG} 10_{340}\right)$ that distinguished the immune parent and progeny from the susceptible parent and progeny (Fig. 1). This marker was further characterized on all 116 progeny. Only three recombinant progeny were observed, thus OPG $10_{340}$ appears to be closely linked to $\operatorname{Lrd1}$. Linkage analysis was done using the software package JoinMap version 2.0 (19). The genetic distance between OPG $10_{340}$ and $L r d 1$ is $\approx 2.6$ Haldane 


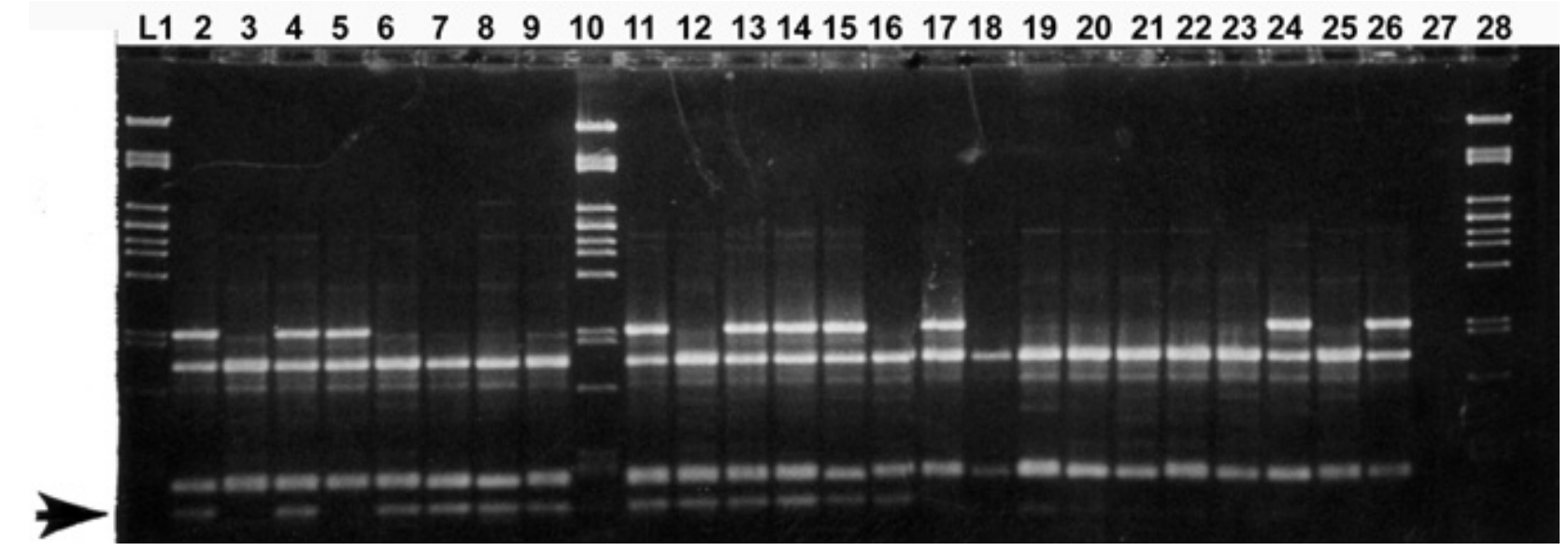

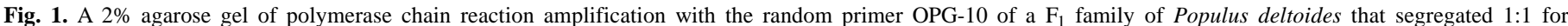

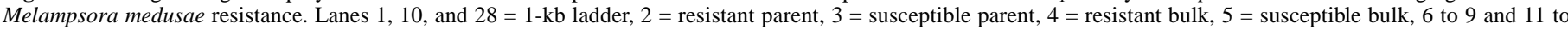
$16=$ resistant progeny, 17 to $26=$ susceptible progeny, and $27=$ control (no template DNA). Arrow indicates the marker OPG10 340 .

centimorgans (cM). The other primer, OPZ-19, also produced a polymorphic band $\left(\mathrm{OPZ} 19_{1800}\right)$ that distinguished the immune parent and progeny from the susceptible parent and progeny. However, upon further characterization in the entire population, a total of eight recombinants were observed for this marker. The genetic distance between OPZ19 1800 and $\operatorname{Lrd} 1$ is $\approx 7.4 \mathrm{cM}$. Multipoint linkage analyses suggest the most likely order for these loci is $L r d 1$, OPG10 $1_{340}$, and OPZ19 $1_{1800}$. This order was 15 times more probable than the next most likely order: OPG $10_{340}, \operatorname{Lrd1}$, and OPZ19 ${ }_{1800}$.

\section{DISCUSSION}

Molecular markers that are linked to plant disease-resistance genes have been instrumental in the cloning of these genes by chromosome walking or landing $(8,12,21)$. Similarly, RAPD markers reported in this study could be used as probes for screening genomic libraries of $P$. deltoides, thereby facilitating the cloning of Lrd1. With a Populus genetic map based on interspecific hybrid families, the physical distance to genetic distance ratio was $\approx 220 \mathrm{~kb} / \mathrm{cM}(2)$. Based on this estimate, RAPD marker OPG $10_{340}$ could be as far as $572 \mathrm{~kb}$ away from $\mathrm{Lrd} 1$. In interspecific hybrids, genetic recombination may be hindered by the presence of nonhomologous chromosomal regions; therefore, the estimate of $220 \mathrm{~kb} / \mathrm{cM}$ may be inflated. Our estimate of genetic distance between $\mathrm{Lrd} 1$ and $\mathrm{OPG} 1 \mathrm{O}_{340}$ is based on data from an intraspecific cross where genetic recombination is less likely to be hindered. Thus, physical distance between the RAPD marker OPG $10_{340}$ and $L r d 1$ might be less than $572 \mathrm{~kb}$. Regardless, we are currently pursuing other markers and employing candidate disease-resistance gene sequences as probe (24) to identify markers more tightly linked to $\operatorname{Lrd} 1$.

Previous studies have reported a locus $M m d 1$ involved in partial resistance to $M$. medusae. This locus was identified in an interspecific family of $P$. deltoides $\times P$. trichocarpa Torr., and was inherited from the $P$. trichocarpa parent (17). Unlike P. deltoides, $P$. trichocarpa is not endemic to the north central United States, and therefore may not have been naturally selected for $M$. medusae resistance. In another study, amplified fragment length polymorphisms were used to identify markers that were tightly linked to $M$. larici-populina $\mathrm{K}$. resistance in a $P$. deltoides $\times P$. nigra $\mathrm{L}$. hybrid family (3). In such interspecific families where the host parent and the pathogen may not have coevolved, manifested resistance could be caused by "exaptions" instead of an evolved resistance mechanism $(6,16)$. Consequently, hybrid families may be of only limited use for identifying and cloning rust-resistance genes that are derived from continued coevolution of $M$. medusae and $P$. deltoides. Lrd1, which imparts immunity and has been identified in an intraspecific $P$. deltoides family, offers a unique opportunity for future studies aimed at cloning a coevolved poplar rust-resistance gene.

Although further supporting evidence is needed, recent reports indicate that in some interspecific hybrid poplar families, genes for quantitative rust resistance to Melampsora sp. may be found clustered with qualitative resistance genes $(11,15)$. If this holds true in $P$. deltoides, the cloning of $L r d 1$ may help identify other genes that also contribute to leaf rust resistance in $P$. deltoides.

In addition to its commercial potential, the genus Populus serves as a model for molecular biology research on woody plants (9). Thus, any progress toward cloning rust-resistance genes is a significant step toward understanding the highly complex interactions within the Populus-Melampsora pathosystem and other woody plant pathosystems.

\section{ACKNOWLEDGMENTS}

Journal Paper J-18639 of the Iowa Agriculture and Home Economics Experiment Station, Ames and projects 3088 and 3443 were supported by Hatch Act and State of Iowa funds. This research was supported under subcontract 19X-43391C with Oak Ridge National Laboratory under Martin-Marietta Energy Systems, Inc. and contract DE-AC05$840 R 214000$ with the U.S. Department of Energy. We acknowledge travel support for G. M. Tabor from the Farnsworth Memorial Funds, Department of Forestry, Iowa State University Foundation. We thank G. N. Johnson and K. B. Davis for technical support and B. McMahon and J. J. Jokela for the parental clones from the University of Illinois.

\section{LITERATURE CITED}

1. Arthur, J. C., and Cummins, G. B. 1962. Manual of Rusts in the United States and Canada. Hafner Publishing Company, New York. pp. 462.

2. Bradshaw, H. D., Jr., Villar, M., Watson, B. D., Otto, K. G., Stewart, S., and Stettler, R. F. 1994. Molecular genetics of growth and development in Populus. III. A genetic linkage map of hybrid poplar composed of RFLP, STS, and RAPD markers. Theor. Appl. Genet. 89:551-558.

3. Cervera, M. T., Gusmno, J., Steenackers, M., Peleman, J., Storme, V., Vanden Broeck, A., Van Montagu, M., and Boerjan, W. 1996. Identification of AFLP molecular markers for resistance against Melampsora larici-populina in Populus. Theor. Appl. Genet. 93:733-737.

4. Doyle, J. J., and Doyle, J. L. 1987. A rapid DNA isolation procedure for small quantities of fresh leaf tissue. Phytochem. Bull. 19:11015.

5. Goue-Mourier, M. C., Faivre-Rampant, P., Le Guerrou J. B., Lefe'vre, F., and Villar, M. 1996. Molecular and genetic approaches to rust resistance (Melampsora sp.) in poplar (Populus sp.). Pages 249-254 in: Somatic Cell Genetics and Molecular Genetics of Trees. M. R. Ahuja, W. Boerjan, and D. B. Neale, eds. Kluwer Academic Publishers, Dordrecht, the Netherlands. 
6. Gould, S. J., and Vrba, E. S. 1982. Exaption: A missing term in the science of form. Paleobotany 8:4-15.

7. Jokela, J. J., and Lovett, W. R. 1975. Selection and breeding eastern cottonwood for resistance to foliage diseases. Pages 122-131 in: Proc. Lake States For. Tree Improve. Conf. U.S. Dep. Agric. For. Serv. Gene Tech. Rep. NC-26.

8. Jones, D. A., Thomas, C. M., Hammond-Kosack, K. E., Balint-Kurti, P. I., and Jones, J. D. G. 1994. Isolation of the tomato Cf-9 gene for resistance to Cladosporium fulvum by transposon tagging. Science 266:789-793.

9. Klopfenstein, N. B., Chun, Y. W., Kim, M.-S., and Ahuja, M. R. 1997. Micropropagation, genetic engineering, and molecular biology of Populus. Page 326 in: Gen. Tech. Rep. RM-GTR-297. U.S. Dep. Agric. For. Ser., Rocky Mt. For. Range Exp. Stn.

10. Larson, P. R., and Isebrands, J. G. 1971. The plastochron index as applied to developmental studies of cottonwood. Can. J. For. Res. 1:1-11.

11. Lefe'vre, F., Goue-Mourier, M. C., Faivre-Rampant, P., and Villar, M. 1998. A single gene cluster controls incompatibility and partial resistance to various Melampsora larici-populina races in hybrid poplars. Phytopathology 88:156-163.

12. Martin, G. B., Brommonschenkel, S. H., Chunwongse, J., Frary, A., Ganal, M. W., Spivey, R., Wu, T., Earle, E. D., and Tanksley, S. D. 1993. Map-based cloning of a protein kinase gene conferring disease resistance in tomato. Science 262:1432-1436.

13. McMahon, B. G., Hanna, R.D., and Hall, R. B. 1994. Selection and breeding of Populus clones in the North Central Region. Proc. North. For. Genet. Assoc. 2:2-12.

14. Michelmore, R. W., Paran, I., and Kesseli, R. V. 1991. Identification of markers linked to disease-resistance genes by bulked segregant analysis: A rapid method to detect markers in specific genomic regions by using segregating populations. Proc. Natl. Acad. Sci. USA 88:9828-9832.

15. Newcombe, G. 1998. Association of $M m d 1$, a major gene for resistance to Melampsora medusae f. sp. deltoidae with quantitative traits in poplar rust. Phytopathology 88:114-121.

16. Newcombe, G. 1998. A review of exapted resistance to diseases of Populus. Eur. J. For. Path. 28:209-216.

17. Newcombe, G., Bradshaw, H. D., Jr., Chastagner, G. A., and Stettler, R. F. 1996. A major gene for resistance to Melampsora medusae f. sp. deltoidae in a hybrid poplar pedigree. Phytopathology 86:87-94.

18. Prakash, C. S., and Thielges, B. A. 1987. Pathogenic variation in Melampsora medusae leaf rust of Populus. Euphytica 36:562-569.

19. Stam, P. 1993. Construction of integrated genetic linkage maps by means of a new computer package: JoinMap. Plant J. 3:739-744.

20. Tabor, G. M., Kubisiak, T., Klopfenstein, N. B., Hall, R. B., and McNabb, H. S., Jr. 1998. Molecular markers linked to Melampsora medusae resistance in Populus deltoides. (Abstr.) Phytopathology 88 (suppl.):S118.

21. Tanksley, S. D., Ganal, M. W., and Martin, G. B. 1995. Chromosome landing: A paradigm for map-based gene cloning in plants with large genomes. Trends Genet. 11:63-68.

22. Widin, K. D., and Schipper, A. L. 1980. Epidemiology of Melampsora medusae leaf rust of poplars in north central United States. Can. J. For. Res. 10:257-263.

23. Williams, J. G. K., Kubelik, A. R., Livak, K. J., Rafalski, J. A., and Tingley, S. V. 1990. DNA polymorphisms amplified by arbitrary primers are useful as genetic markers. Nucleic Acids Res. 18:6531-6535.

24. Yu, Y. G., Buss, G. R., and. Saghai-Maroof, M. A. 1996. Isolation of a superfamily of candidate disease-resistance genes in soybean based on a conserved nucleotide-binding site. Proc. Natl. Acad. Sci. USA 93:1175111756.

25. Ziller, W. G. 1965. Studies of western tree rusts. VI. The aecial host ranges of Melampsora albertensis, M. medusae, and M. occidentalis. Can. J. Bot. 43:221-238. 